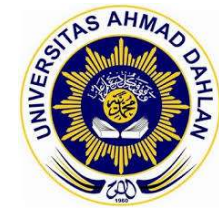

BERKALA FISIKA INDONESIA

Jurnal IImiah Fisika, Pembelajaran dan Aplikasinya

http://journal.uad.ac.id/index.php/BFl/index

2085-0409 (Print) |2550-0465 (online)

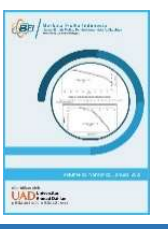

\title{
Respon peserta didik terhadap program edmodo dalam model pembelajaran blended learning
}

\section{Ainun Fuadah ${ }^{1 *}$, Susilawati ${ }^{2}$, Agatha Hadi Nugraha ${ }^{3}$, Dwi Sulisworo ${ }^{4}$}

1,2,3,4 Magister Pendidikan Fisika, Fakultas Keguruan dan Ilmu Pendidikan, Universitas Ahmad Dahlan, Indonesia

Email: fuadah.ai@gmail.com*

* Penulis korespondensi

\begin{tabular}{ll}
\hline \multicolumn{2}{l}{ Informasi artikel } \\
\hline Sejarah artikel: & \\
Dikirim & $17 / 03 / 21$ \\
Revisi & $18 / 04 / 21$ \\
Diterima & $19 / 04 / 21$ \\
\hline
\end{tabular}

Kata kunci:

Blended Learning

Edmodo

\section{Keywords:}

Blended Learning

Edmodo

\begin{abstract}
ABSTRAK
Penelitian ini bertujuan untuk mengetahui tingkat respon peserta didik pada program Edmodo dalam model pembelajaran Blended Learning yang telah diimplementasikan selama 3 bulan. Subyek coba adalah peserta didii kelas X SMKN 3 Banjar dengan jumlah sampel 35 orang. Penelitian ini merupakan penelitian kualitatif dengan menggunakan instrumen penelitian berupa angket. Analisis data dilakukan secara deskriptif dengan penskoran. Hasil analisis menunjukkan bahwa $46 \%$ partisipan merasa puas dan $54 \%$ partisipan merasa sangat puas terhadap program Edmodo. Partisipan juga menilai bahwa program Edmodo membantu mereka dalam belajar serta mudah digunakan dan dipelajari.
\end{abstract}

This is an open access article under the CC-BY-SA license

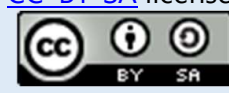

\section{ABSTRACT}

Student response to edmodo program in blended learning model. This study aims to find out the response rate of students in the Edmodo program in the Blended Learning learning model that has been implemented for 3 months. The test subjects were participants in class X SMKN 3 Banjar with a sample number of 35 people. This research is qualitative research using research instruments in the form of questionnaires. Data analysis is done descriptively with scoring. The results showed that $46 \%$ of participants were satisfied and $54 \%$ of participants were very satisfied with the Edmodo program. Participants also assessed that the Edmodo program helped them in learning and was easy to use and learn.

\section{How to Cite:}

Fuadah, A., Susilawati, Nugraha, A. H., \& Sulisworo, D. (2021). Respon peserta didik terhadap program edmodo dalam model pembelajaran blended learning. Berkala Fisika Indonesia: Jurnal Ilmiah Fisika, Pembelajaran dan Aplikasinya, 12(2), 49-53. 


\section{Pendahuluan}

Abad 21 merupakan era yang menuntut kemudahan serta keterbukaan informasi dan akses layanan publik dalam semua sektor. Misalnya: sektor industri, kesehatan, dan pendidikan. Hal ini disebabkan perkembangan teknologi merupakan hal yang tidak bisa dibendung dan telah menjadi kebutuhan yang tidak bisa dihindari (Ngafifi, 2014). Masyarakat abad 21 baik sebagai penyedia maupun pengguna informasi dan layanan publik harus memiliki kemampuan untuk menyediakan, mengakses serta menggunakan teknologi dan media dengan berbagai cara yang inovatif (Aka, 2017; Rahardja et al., 2019). Oleh karena itu, inovasi dalam ranah pemikiran, konsep dan tindakan harus terus menerus dilakukan. Hal ini berimbas dalam dunia pendidikan. Dalam rangka menciptakan manusia yang berkualitas, pendidikan dilaksanakan dengan baik dan profesional mengacu pada standar pelayanan pendidikan abad 21 (Andriani, 2010). Untuk menjawab tantangan abad 21, dunia pendidikan harus menyadari minimal dua hal yakni menyadari siapa peserta didiknya dan kemampuan apa yang seharusnya mereka miliki (Arifin, 2017; Janaha, Suyitnob, \& Rosyida, 2019). Sekolah perlu menyadari bahwa peserta didik mereka adalah anak-anak yang oleh Mc Crindle dan Som Yew Ya disebut sebagai generasi Z dan generasi Alpha. Generasi Z atau dikenal dengan iGen merupakan generasi yang dilahirkan pada tahun 1999 - 2009 dan dunia digital menjadi sesuatu yang tidak terpisahkan dari mereka (Bejtkovsky, 2016). Bagi mereka, teknologi merupakan sarana untuk berkomunikasi, bermain, berkarya dan menunjukkan eksistensi diri. Sedangkan generasi Alpha atau generasi A adalah generasi yang lahir sejak tahun 2010 (Nagy \& Kölcsey, 2017). Mereka adalah generasi milenial yang lahir dan tumbuh sepenuhnya pada abad 21 di mana teknologi sudah bertumbuh pesat dan mudah diakses. Generasi ini akan menjadi generasi yang paling terdidik karena mereka akan menikmati sistem pendidikan yang telah disiapkan dengan lebih baik. Hal ini tentu tidak terlepas dari usaha dunia pendidikan dalam mempersiapkan peserta didik (generasi Z dan Alpha) supaya mempunyai kompetensi untuk menjawab kebutuhan abad 21.

Pada masa kini, pengelola sekolah dan pendidik adalah generasi yang lahir sebelum generasi Z dan mempunyai perbedaan kemampuan menggunakan TIK dengan peserta didiknya. Pengelola sekolah dan pendidik harus terburu-buru mengejar ketertinggalan dan berusaha mempersempit gap antar generasi tersebut karena mereka adalah faktor penting dalam menentukan kualitas generasi sesudahnya. Keterlibatan guru dan teknologi secara seimbang dalam proses pembelajaran akan membantu ketercapaian hasil belajar peserta didik secara maksimal dan jika kedua faktor tersebut tidak mempunyai porsi yang seimbang justru akan berimbas pada berkurangnya kualitas pembelajaran di kelas (Yuhdi \& Amalia, 2018). Kurangnya porsi keterlibatan guru dan berlebihnya porsi penggunaan teknologi akan berakibat pada kurangnya kedisiplinan, sedangkan kurangnya porsi penggunaan teknologi dan berlebihnya keterlibatan guru dalam pembelajaran mengakibatkan peserta didik bosan, tidak terinspirasi dan tidak bersemangat (Johnson, 2013). Pendidik harus memiliki dan mengembangkan

50 Berkala Fisika Indonesia : Jurnal Ilmiah Fisika, Pembelajaran dan Aplikasinya Vol. 12 No. 2, Juli 2021 | $49-53$ 
kualitas kemampuan penggunaan TIK dan memanfaatkannya sebagai alat bantu pembelajaran untuk menciptakan pengalaman belajar yang bermakna, meningkatkan motivasi dan prestasi belajar peserta didik. Internet dan teknologi informasi visualisasi dan simulasi yang beragam bisa membantu peserta didik untuk merekonstruksi pengetahuan dan informasi yang sebelumnya sudah mereka dapatkan, mengobservasi peristiwa dengan instrumen jarak jauh, dan menjalin komunikasi dengan pendidik di seluruh belahan dunia (Lombardi, 2007).

Peserta didik sebagai generasi masa depan, setidaknya harus memiliki empat (4) keterampilan abad 21 yakni keterampilan berfikir kritis dan berinovasi (Critical Learning and Innovation Skills), keterampilan untuk hidup dan berkarir/berkarya (Life and Career Skills), keterampilan sosial dan silang budaya (Social and Cross-Cultural Skills) dan keterampilan yang berhubungan dengan pemanfaatan media, informasi dan teknologi (Information, Media, and Technology Skills) ("Partnership for 21st Century Learning, 'P21,'" n.d.). Peserta didik membutuhkan banyak latihan untuk mengembangkan dan menyempurnakan keterampilan abad 21 mereka supaya bisa memecahkan masalah yang dihadapi dengan lebih baik dan membuat berbagai inovasi yang lebih kreatif (Center, 2010). Tantangan yang dihadapi oleh mereka tidak sama dengan tantangan generasi sebelumnya. Oleh karena itu, sekolah harus menyediakan lingkungan belajar dan kesempatan yang mendukung keterampilan di atas. Kurikulum sekolah didesain untuk menciptakan lingkungan belajar yang berpusat pada kolaborasi peserta didik (Boholano, 2017). Selain itu, sekolah juga harus mendorong terwujudnya literasi teknologi, informasi dan komunikasi/TIK yang meleburkan batasan antara pembelajaran pengetahuan dan teknologi di mana keduanya menjadi saling terkait.

Implementasi peningkatan pemanfaatan teknologi di sekolah sudah pasti akan membawa kesulitan tersendiri bagi sekolah, baik dalam hal kesiapan guru juga masalah pendanaan. Beberapa peneliti menyarankan adanya kerjasama sekolah dengan pihak luar sebagai mitra sekolah yang mempunyai kepentingan yang sama (Wijaya, Sudjimat, \& Nyoto, 2016). Salah satu penerapan pemanfaatan teknologi dalam proses pembelajaran adalah melaksanakan pembelajaran dengan model pembelajaran Blended Learning berbantuan Program Edmodo seperti yang telah dilakukan di SMKN 3 Banjar. Penggunaan Program Edmodo dalam pembelajaran telah digunakan selama 3 bulan sehingga dilakukan evaluasi. Penelitian ini bertujuan untuk mengetahui persepsi peserta didik terhadap program Edmodo.

\section{Metode}

Jenis penelitian yang digunakan adalah penelitian kualitatif dengan membagikan angket kepada subyek penelitian. Penelitian ini dilaksanakan oleh peneliti pada tanggal 12 November 2018 dilaksanakan di SMKN 3 Banjar. Subjek coba dalam penelitian ini adalah siswa sekolah menengah kejuruan yaitu peserta didik kelas $X$ sebanyak 35 orang sebagai pengguna. Instrumen penelitian yang digunakan berupa angket untuk mengukur kepuasan peserta didik (7 item), kemanfaatan edmodo dalam 
membantu peserta didik untuk belajar (8 item), kemudahan program edmodo untuk digunakan dan dipelajari oleh peserta didik masing-masing 11 item dan 4 item,. Data yang didapatkan dihitung dengan menggunakan rumus di bawah ini [20].

$$
P=\frac{f}{N} \times 100 \%
$$

dengan $N$ adalah jumlah skor tertinggi, dan $f$ adalah skor yang di dapatkan dari subyek coba yang memberikan jawaban dan $p$ adalah presentase ketercapaian skor. Sesuai kriteria penilaian seperti pada Tabel 1:

Tabel 1. Interval nilai untuk tingkat respon subyek coba terhadap program Edmodo

\begin{tabular}{cc} 
Interval (\%) & Kriteria Tingkat respon \\
\hline $79<\mathrm{P} \leq 100$ & Sangat puas atau Sangat Setuju \\
$65<\mathrm{P} \leq 79$ & Puas atau Setuju \\
$55<\mathrm{P} \leq 65$ & Tidak Puas atau Tidak Setuju \\
$0<\mathrm{P} \leq 55$ & Sangat Tidak Puas atau Sangat Tidak Setuju \\
\hline
\end{tabular}

\section{Hasil dan Pembahasan}

Penelitian evaluasi program Edmodo ini bertujuan untuk mengetahui tingkat kepuasan dan kemudahan program tersebut bagi peserta didik sebagai media pembelajaran fisika untuk sekolah menengah kejuruan. Secara keseluruhan berdasarkan penilaian peserta didik sebagai pengguna diperoleh data seperti pada diagram batang hasil respon peserta didik.

Pada Gambar 1 diketahui terdapat empat (4) jenis respon yang terukur. Pertama, tingkat kemanfaatan program Edmodo dalam pembelajaran Blended Learning yang dirasakan oleh peserta didik adalah sebesar $52 \%$ pada level bermanfaat dan $48 \%$ pada level sangat bermanfaat dalam pembelajaran dengan menggunakan model pembelajaran blended learning. Kedua, tingkat kemudahan penggunaan Edmodo menurut peserta didik adalah sebesar $55 \%$ program Edmodo mudah digunakan dan $45 \%$ sangat mudah digunakan. Ketiga, tingkat kemudahan program Edmodo untuk dipelajari oleh peserta didik adalah sebesar $49 \%$ pada level mudah dan $51 \%$ pada level sangat mudah dipelajari. Keempat, tingkat kepuasan peserta didik dalam menggunakan program Edmodo sebesar $46 \%$ pada level puas dan $54 \%$ pada level sangat puas.

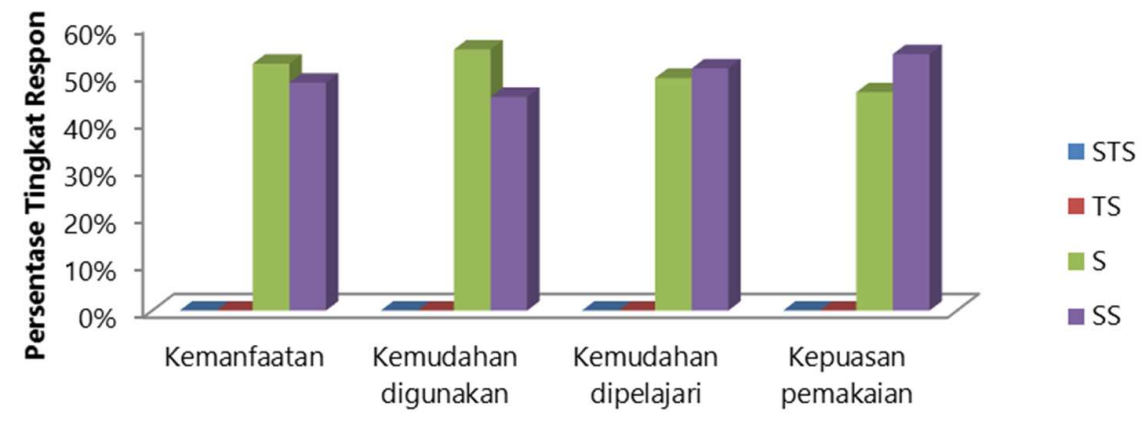

Jenis Respon Peserta didik

Gambar 1. Diagram batang hasil respon peserta didik 


\section{Simpulan}

Berdasarkan hasil penelitian yang telah dilakukan, maka diperoleh kesimpulan bahwa respon peserta didik pada program edmodo hasil analisis menunjukkan bahwa $46 \%$ partisipan merasa puas dan $54 \%$ partisipan merasa sangat puas terhadap program Edmodo. Partisipan juga menilai bahwa program Edmodo membantu mereka belajar serta mudah digunakan dan dipelajari

\section{Referensi}

Aka, K. A. (2017). Pemanfaatan teknologi informasi dan komunikasi (TIK) sebagai wujud inovasi sumber belajar di Sekolah Dasar. ELSE (Elementary School Education Journal): Jurnal Pendidikan dan Pembelajaran Sekolah Dasar, 1(2).

Andriani, D. E. (2010). Mengembangkan profesionalitas guru abad 21 melalui program pembimbingan yang efektif. Jurnal Manajemen Pendidikan, VI(2), 78-92.

Arifin, Z. (2017). Mengembangkan instrumen pengukur critical thinking skills siswa pada pembelajaran matematika abad 21. Jurnal THEOREMS (The Original Research of Mathematics), 1(2), 92-100.

Bejtkovsky, J. (2016). The employees of baby boomers generation, generation $\mathrm{X}$, generation $\mathrm{Y}$ and generation $\mathrm{Z}$ in selected czech corporations as conceivers of development and competitiveness in their corporation. Journal of Competitiveness, 8(4), 105-123.

Boholano, H. (2017). Smart social networking: 21st century teaching and learning skills. Research in Pedagogy, 7(2), 21-29.

Center, P. P. R. (2010). 21st century skills for students and teachers. Honolulu: Kamehameha Schools, Research \& Evaluation Division.

Janaha, S. R., Suyitnob, H., \& Rosyida, I. (2019). Pentingnya literasi matematika dan berpikir kritis matematis dalam menghadapi abad ke-21. PRISMA, Prosiding Seminar Nasional Matematika, 905-910. Semarang: Jurusan Matematika, Universitas Negeri Semarang.

Johnson, A. (2013). Effective methods for 21st century learning: A teacher action research project. Meridian: A K-16 School Computer Technologies Journal, 16(2), 1-14.

Lombardi, M. M. (2007). Authentic learning for the 21st century: An overview. Educause Learning Initiative, 1 (2007), $1-12$.

Nagy, Á., \& Kölcsey, A. (2017). Generation alpha: Marketing or science. Acta Technologica Dubnicae, 7(1), $107-115$.

Ngafifi, M. (2014). Kemajuan teknologi dan pola hidup manusia dalam perspektif sosial budaya. Jurnal Pembangunan Pendidikan: Fondasi dan Aplikasi, 2(1), 33-47.

Partnership for 21st Century Learning, "P21." (n.d.). Retrieved from http://www.p21.org/storage/documents/docs/P21_Framework_Definitions_New_Logo_2015.pdf

Rahardja, U., Lutfiani, N., Lestari, A. D., \& Manurung, E. B. P. (2019). Inovasi perguruan tinggi raharja dalam era disruptif menggunakan metodologi iLearning. Jurnal Ilmiah Teknologi Informasi Asia, 13(1), 23-34.

Wijaya, E. Y., Sudjimat, D. A., \& Nyoto, A. (2016). Transformasi pendidikan abad 21 sebagai tuntutan pengembangan sumber daya manusia di era global. In Prosiding Seminar Nasional Pendidikan Matematika 2016, 263-278. Malang: Universitas Kanjuruhan Malang.

Yuhdi, A., \& Amalia, N. (2018). Desain media pembelajaran berbasis daring memanfaatkan portal Schoology pada pembelajaran apresiasi sastra. Basastra, 7(1), 14-22. 